Cellular Physiology
and Biochemistry and Biochemistry Published online: July 07,2016

Accepted: May 31, 2016

This article is licensed under the Creative Commons Attribution-NonCommercial-NoDerivatives 4.0 International License (CC BY-NC-ND) (http://www.karger.com/Services/OpenAccessLicense). Usage and distribution for commercial purposes as well as any distribution of modified material requires written permission.

Original Paper

\title{
Tyrosine Mutation in AAV9 Capsid Improves Gene Transfer to the Mouse Lung
}

\author{
Sabrina V. Martinia Adriana L. Silva ${ }^{a, b}$ Debora Ferreira ${ }^{a}$ Rafael Rabelo ${ }^{a}$ \\ Felipe M. Ornellas ${ }^{a}$ Karina Gomes ${ }^{a}$ Patricia R.M. Rocco ${ }^{b}$ Hilda Petrs-Silva ${ }^{c}$ \\ Marcelo M. Morales ${ }^{a}$ \\ aLaboratory of Cellular and Molecular Physiology, 'baboratory of Pulmonary Investigation, 'Laboratory \\ of Neurogenesis, Carlos Chagas Filho Institute of Biophysics, Federal University of Rio de Janeiro, Rio \\ de Janeiro, Ilha do Fundão, Brazil
}

\section{Key Words}

Adeno-associated virus serotype $9 \cdot$ Tyrosine mutant $\bullet$ Gene therapy $\bullet$ Lung mechanics

\begin{abstract}
Background/Aims: Adeno-associated virus (AAV) vectors are being increasingly used as the vector of choice for in vivo gene delivery and gene therapy for many pulmonary diseases. Recently, it was shown that phosphorylation of surface-exposed tyrosine residues from AAV capsid targets the viral particles for ubiquitination and proteasome-mediated degradation, and mutations of these tyrosine residues lead to highly efficient vector transduction in vitro and in vivo in different organs. In this study, we evaluated the pulmonary transgene expression efficacy of AAV9 vectors containing point mutations in surface-exposed capsid tyrosine residues. Methods: Eighteen C57BL/6 mice were randomly assigned into three groups: (1) a control group (CTRL) animals underwent intratracheal (i.t.) instillation of saline, (2) the wildtype AAV9 group (WT-AAV9, $10^{10} \mathrm{vg}$ ), and (3) the tyrosine-mutant Y731F AAV9 group (MAAV9, $10^{10} \mathrm{vg}$ ), which received (i.t.) self-complementary AAV9 vectors containing the DNA sequence of enhanced green fluorescence protein (eGFP). Four weeks after instillation, lung mechanics, morphometry, tissue cellularity, gene expression, inflammatory cytokines, and growth factor expression were analyzed. Results: No significant differences were observed in lung mechanics and morphometry among the experimental groups. However, the number of polymorphonuclear cells was higher in the WT-AAV9 group than in the CTRL and M-AAV9 groups, suggesting that the administration of tyrosine-mutant AAV9 vectors was better tolerated. Tyrosine-mutant AAV9 vectors significantly improved transgene delivery to the lung (30\%) compared with their wild-type counterparts, without eliciting an inflammatory response. Conclusion: Our results provide the impetus for further studies to exploit the use of AAV9 vectors as a tool for pulmonary gene therapy.

\section{Introduction}

Delivery of therapeutic genes to the unhealthy airway epithelium in vivo is a promising option for gene therapy of lung diseases including cystic fibrosis, $\alpha$-1-antitrypsin deficiency, 
chronic obstructive pulmonary disease, pulmonary hypertension, and lung cancer [1-5].Of the many viral vectors, adeno-associated virus (AAV) vectors appear to be the most advantageous for gene transfer due to their efficient transduction, long-term gene expression, low immunogenicity, and a lack of apparent cytotoxicity in tissues [6]. Currently, 12 serotypes of AAV (AAV1 to AAV12) vectors have been studied extensively as gene therapy vectors [7]. These AAV serotypes share a common genome, but their unique capsid structure helps them to recognize different cell-surface receptors [8]. Thus, a safe and efficacious AAV vector is presumed to be defined by the capsid, which also affects gene transfer tropism, gene transfer efficiency, immune activation, and susceptibility [9].

AAV serotype 2 is the most widely studied but has demonstrated limited preclinical and clinical success $[10,11]$. The capsid antigens of AAV2 are known to elicit an inflammatory response that affects airway and lung parenchyma leading to a reduction in gene transfer [12]. To overcome the dose-dependent immunotoxicity limitations imposed by AAV2 vectors, alternate AAV serotypes and tyrosine-mutant AAV vectors are being evaluated for lung gene transfer [13]. In some cases, knowledge of delivery mechanisms coupled with AAV structural analyses can help to improve the vectors [14]. Improved AAV vectors should provide enhanced transduction efficiency with a lower vector dose requirement and better safety profile [15].

It is known that, during intracellular trafficking, $\mathrm{AAV}$ vectors are targeted for destruction in the cytoplasm by the host-cellular kinase/ubiquitination/proteasomal machinery [13]. Advances in molecular biology have enabled the design of site-mutated AAV in an attempt to modulate AAV tropism to increase its transducing efficiency [6]. Site-directed tyrosine to phenylalanine (Y-F) mutagenesis of surface-exposed tyrosine residues on AAV2 capsids circumvents the ubiquitination step, thereby avoiding proteasome-mediated degradation and resulting in high-efficiency transduction of mutant vectors relative to the wild-type AAV2 vector, both in cell culture and in vivo murine hepatocytes [16]. Furthermore, Petrs-Silva et al. [17] reported a 10- to 20-fold increase in transduction efficiency in mouse retina using tyrosine-mutant AAV2, AAV8, and AAV9 vectors compared with their wild-type counterparts. This approach was used recently to engineer a novel AAV tyrosine to phenylalanine mutant capsid with a potentially reduced risk of cytotoxic $\mathrm{T}$ lymphocyte immune responses, which is a key limitation of clinical AAV-mediated gene therapy [18].

Vectors based on AAV9, which has been isolated from human tissues, are promising for gene therapy [19]. AAV9 has been shown to have significant capacity to target the heart for treatment of cardiomyopathies [20] and neurons for treating diseases such as spinal muscular atrophy [21]. In addition, AAV9 has been shown to transduce airways remarkably well and display lower immunogenicity in comparison with AAV2 vectors [22]. AAV9 serotypes have been implicated in binding the laminin receptor, which has been shown to be expressed in developing and adult lungs [23].

Furthermore, aiming to increase gene transfer in vitro and in vivo and reduce vector dose delivery, Qiao et al. [15] performed site-directed mutations of tyrosine to phenylalanine (Y446F or Y731F) on the surface of AAV9 capsids and demonstrated that this single mutation was insufficient to enhance gene delivery to skeletal muscle and the heart.

Therefore, despite its ability to transduce numerous tissues, no data are available on the transduction efficiency and possible functional and histologic damage in lungs subjected to tyrosine-mutant AAV9. Thus, our aim was determine whether tyrosine-mutant AAV9 is highly efficient for gene transfer to the lungs. Moreover, we evaluated if the administration of AAV9 vector caused an inflammatory response and lung damage, thus altering pulmonary morphofunction.

\section{Materials and Methods}

All animal experiments and procedures were approved by the Ethics Committee of the Health Sciences Center, Federal University of Rio de Janeiro. The animals received humane care in compliance with the Prin- 


\section{Cellular Physiology Cell Physiol Biochem 2016;39:544-553 \\ \begin{tabular}{cc|cc} 
DOI: 10.1159/000445646 & $\begin{array}{l}\text { O } 2016 \text { The Author(s). Published by S. Karger AG, Basel } \\
\text { www.karger.com/cpb }\end{array}$
\end{tabular} \\ Martini et al.: Mutation in AAV9 Improves Gene Transfer to the Lung}

ciples of Laboratory Animal Care formulated by the National Council for Control of Animal Experimentation (CONCEA), Brazil. The protocols involving animals were approved by the Ethics Committee on Animal Use (CEUA) from the Health Sciences Center (CCS), Federal University of Rio de Janeiro.

\section{Generation of rAAV vectors}

Surface-exposed tyrosine $(\mathrm{Y})$ residues on AAV9 capsids underwent site-directed mutation to phenylalanine (F) to alter the vector transduction characteristics, as previously described [16]. This site-directed mutation resulted in the generation of tyrosine-mutant Y731F AAV9. Vector preparations were produced using the plasmid co-transfection method [17]. The crude iodixanol fraction, as described, was further purified and concentrated by column chromatography on a 5-ml HiTrap Q Sepharose column using a Pharmacia AKTA FPLC system (Amersham Biosciences, Piscataway, NJ). The vector was eluted from the column using $215 \mathrm{mM} \mathrm{NaCl}(\mathrm{pH} \mathrm{8.0)}$ ) and the rAAV peak was collected. Vector-containing fractions were then concentrated and buffer exchanged in Alcon BSS with 0.014\% Tween 20, using a Biomax 100K concentrator (Millipore, Billerica, MA). Vector was then titered for DNase-resistant vector genomes by real-time polymerase chain reaction (PCR) relative to a standard. The purity of the vector was validated by silver-stained sodium dodecyl sulfate polyacrylamide gel electrophoresis, assayed for sterility and lack of endotoxin, and then aliquoted and stored at $-80^{\circ} \mathrm{C}$.

\section{Treatment groups}

Male C57BL/6 mice (20-25 g) were randomly assigned into three groups ( $n=6$ /group). In the control group (CTRL), $50 \mu \mathrm{l}$ of saline were instilled intratracheally. The wild-type capsid AAV9 (WT-AAV9) group or the capsid tyrosine-mutant Y731F AAV9 (M-AAV9) group $\left(10^{10} \mathrm{vg}\right.$ in $50 \mu \mathrm{l}$ of saline/mouse) containing the DNA of enhanced green fluorescence protein (eGFP) was delivered to mice lungs (Fig. 1). The eGFP expression is under the control of a small chicken $\beta$-actin (smCBA) promoter.

The self-complementary tyrosine-mutant Y731F AAV9 was provided by Dr Hilda Petrs-Silva, Laboratory of Neurogenesis, Carlos Chagas Filho Institute of Biophysics, Federal University of Rio de Janeiro.

\section{Experimental protocol}

The animals were anesthetized with sevoflurane, a 1-cm-long midline cervical incision was made to expose the trachea, and either microparticle or vehicle was instilled intratracheally with a microsprayer (intratracheal aerosolizer, IA-1C S/M-551 Model, Penn-Century, Philadelphia, PA) attached to an FMJ-250 highpressure syringe (Penn-Century, Philadelphia, PA). After instillation, the cervical incision was closed with 5.0 silk suture and the mice were returned to their cage. The animals recovered rapidly after surgery.

\section{Mechanical parameters}

Twenty-eight days after the intratracheal instillation, the animals were sedated (diazepam $1 \mathrm{mg}$ intraperitoneally (i.p.)), anesthetized (thiopental sodium $20 \mathrm{mg} / \mathrm{kg}$ i.p.), tracheotomized, and paralyzed (vecuronium bromide, $0.005 \mathrm{mg} / \mathrm{kg}$ intravenously). The mice were connected to a computer-controlled small-animal ventilator and quasi-sinusoidally ventilated (FlexiVent; SCIREQ, Montreal, Canada), as previously described [24], with a tidal volume of 7.5 $\mathrm{ml} / \mathrm{kg}$ at a frequency of 150 breaths $/ \mathrm{min}$ and a positive end-expiratory pressure of $2 \mathrm{~cm} \mathrm{H}_{2} \mathrm{O}$. The mice were allowed to acclimate to the ventilator for 2-3 min before taking readings, and three to four total lung-capacity functions were performed during this acclimation period to prevent atelectasis and to ensure maximum airway and alveolar recruitment.

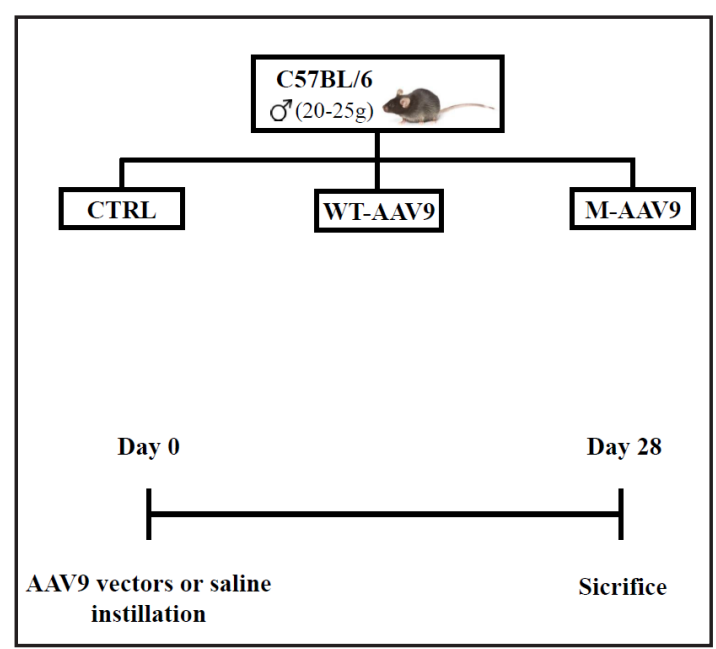

Fig. 1. (A) Schematic flow chart and (B) timeline of the study design. Animals received an intratracheal instillation of saline (CTRL, $50 \mu \mathrm{l}$ of saline), wildtype AAV9 (WT-AAV9, $10^{10} \mathrm{vg} / 50 \mu \mathrm{l}$ of saline), or tyrosine-mutant AAV9 (M-AAV9, $10^{10} \mathrm{vg} / 50 \mu \mathrm{l}$ of saline). Animals were harvested on day 28. 


\section{Cellular Physiology Cell Physiol Biochem 2016;39:544-553 \begin{tabular}{ll|l} 
DOI: 10.1159/000445646 & $\begin{array}{l}\text { @ 2016 The Author(s). Published by S. Karger AG, Basel } \\
\text { wwww.karger.com/cpb }\end{array}$
\end{tabular} \\ Martini et al.: Mutation in AAV9 Improves Gene Transfer to the Lung}

Static elastance was calculated from pressure-volume curves with FlexiVent software (version 5.1). Thirty seconds after each pressure-volume curve, a 2-s perturbation at a frequency of $2.5 \mathrm{~Hz}$ was applied to generate data using the single-compartment model of respiratory mechanics. Only measurements with a coefficient of determination of 0.95 or greater were used, and the measurements were repeated until a total of three pressure-volume curves and three single-compartment perturbations, each with acceptable coefficients of determination, were obtained. The averages of these three measurements were determined for each mouse and then averaged for each experimental group.

Lung histology

A laparotomy was done immediately after the determination of lung mechanics and heparin (1000 IU) was injected intravenously into the vena cava. The trachea was clamped at end expiration, and the abdominal aorta and vena cava were sectioned, leading to a massive hemorrhage that quickly killed the animals. The right lung was then removed, fixed in $3 \%$ buffered formaldehyde and embedded in paraffin. Slices were cut (4- $\mu \mathrm{m}$ thick) and stained with hematoxylin-eosin. Lung histology analysis was performed with an integrated eyepiece using a coherent system consisting of a grid with 100 points and 50 lines (known length) coupled to a conventional light microscope (Olympus BX51, Olympus Latin America-Inc., Brazil). The volume fraction of collapsed and normal pulmonary areas and the number of mononuclear and polymorphonuclear cells in the pulmonary tissue were determined using the point-counting technique across ten random, non-coincident microscopic fields [25].

\section{Immunohistochemistry}

The left lung was removed after measurement of lung mechanics and fixed in $4 \%$ paraformaldehyde in sodium phosphate buffer at $\mathrm{pH} 7.4$ for $24 \mathrm{~h}$. The tissue was then washed in sodium phosphate buffer followed by $30 \%$ sucrose in the same buffer for $24 \mathrm{~h}$. The lung was oriented under a dissection microscope in an aluminum chamber filled with optimal cutting temperature embedding medium, and $10-\mu \mathrm{m}$-thick transverse sections were cut in a cryostat. Tissue sections were first washed in phosphate-buffered saline (PBS) for $5 \mathrm{~min}$, incubated in $50 \mathrm{mM}$ ammonium chloride for $30 \mathrm{~min}$, washed in PBS for $5 \mathrm{~min}$, then incubated with 0.5\% Triton X-100 for $15 \mathrm{~min}$, washed three times with PBS for $5 \mathrm{~min}$ each, followed by incubation with a blocking solution of $1 \%$ albumin for $30 \mathrm{~min}$. The sections were then incubated with an antibody raised against the green fluorescent protein (Invitrogen, Molecular Probes, Carlsbad, CA) at 1:400 in blocking solution overnight at $4^{\circ} \mathrm{C}$. Fluorescent staining was done with an anti-rabbit IgG secondary antibody, Alexa Fluor 488 (Molecular Probes) by incubating sections for $2 \mathrm{~h}$ at room temperature. The nuclei of the tissue cells were labeled with $1 \mu \mathrm{M}$ TO-PRO-3 dye (Invitrogen, Molecular Probes) in PBS for $15 \mathrm{~min}$, then washed three times for 5 min in PBS. The specimens were mounted in ProLong Gold antifade reagent (Invitrogen, Molecular Probes). As a negative control for the technique, we used frozen tissue sections from all experimental groups incubated just with secondary antibody. The results were examined by fluorescence microscopy using an Axiophot microscope (Zeiss, Thornwood, NY). Digital pictures were taken with a camera connected to the Axiophot microscope. Only intensities above the threshold, above the intensity of the negative controls, were considered positive.

\section{Real-time PCR}

Quantitative real-time reverse transcription (RT)-PCR was performed to measure the relative levels of mRNA transcription of eGFP, vascular interleukin (IL)-1 $\beta$, IL-6, IL-13, interferon (IFN)- $\gamma$, and transforming growth factor (TGF)- $\beta$. Central slices of left lung were cut, collected in cryotubes, quick frozen by immersion in liquid nitrogen, and stored at $-80^{\circ} \mathrm{C}$. Total RNA was extracted from the frozen tissues using an RNeasy Plus Mini Kit (Qiagen, Valencia, CA) according to the manufacturer's recommendations. The concentration of RNA was measured by spectrophotometry in Nanodrop ND-1000 (Thermo Scientific, Wilmington, DE). First-strand cDNA was synthesized from total RNA using the QuantiTect Reverse Transcription Kit (Qiagen, Valencia, CA). Relative mRNA levels were measured with an SYBR green detection system using Mastercycler ep realplex (Eppendorf, Hamburg, Germany). All samples were measured in triplicate. The relative mRNA level of each gene was calculated as a ratio of the studied gene to control gene (acidic ribosomal phosphoprotein P0; 36B4). The PCR primers used were eGFP (green fluorescent protein, Qiagen, Valencia, CA), IL-1 $\beta$, IL-6, IL-13, IFN- $\gamma$, TGF- $\beta$, 36B4-Rplp0 (Invitrogen, Carlsbad, CA) as previously described [26].

\section{KARGER}




\section{Cellular Physiology Cell Physiol Biochem 2016;39:544-553

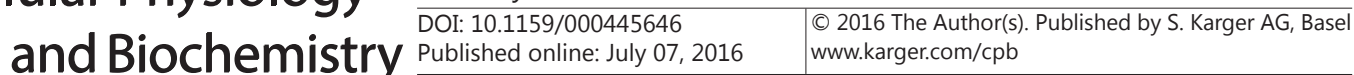 \\ Martini et al:: Mutation in AAV9 Improves Gene Transfer to the Lung}

Statistical analysis

Differences between groups were evaluated with GraphPad Prism software (GraphPad, La Jolla, CA) using one-way ANOVA followed by the Tukey post-test for group comparison and significance was established at $P<0.05$. All data are expressed as the mean \pm standard error of the mean.

\section{Results}

Lung cell gene transfer

With the aim of improving the potential of AAV vectors for pulmonary gene therapy, we analyzed the transduction of AAV9 vectors into mice lung 4 weeks after infection. First, we assessed transgene expression by immunohistochemistry to determine the cellular pattern of transduction and to visualize eGFP-labeled cells. WT-AAV9 showed sparse eGFP expression in the tissue (Fig. 2C, D), whereas the M-AAV9 showed high-intensity eGFP fluorescence throughout the tissue cells compared with WT-AAV9. Evidently more cells were transduced with the M-AAV9 vector.

\section{Analysis of eGFP transcription}

eGFP mRNA expression in the lung was examined by real-time PCR to determine the transduction efficacy of AAV9 vectors. The analysis demonstrated that the eGFP level was $30 \%$ higher in the M-AAV9 group $(8.490 \pm 0.2675, n=5, P<0.05)$ compared with the WTAAV9 group (6.503 $\pm 0.4334, n=5, P<0.05)$ (Fig. 2G).

\section{Lung histology}

Lung morphometry and tissue cellularity were analyzed in order to identify whether the administration of AAV9 vectors to the airways induced histologic changes in the lung

Fig. 2. $(\mathrm{A}-\mathrm{F}) \mathrm{Re}-$ presentative photomicrographs of immunohistochemistry for eGFP. Analysis of eGFP expression 4 weeks after intratracheal instillation of saline (CTRL, 50 $\mu \mathrm{l}$ of saline) (A, B) and AAV9 vectors at an equal dose of $10^{10}$ per mouse of wild-type (WTAAV9) (C, D) or its tyrosine-mutant (M-AAV9) (E, F). Immunohistochemistry for eGFP (A, $\mathrm{C}$, and E); double

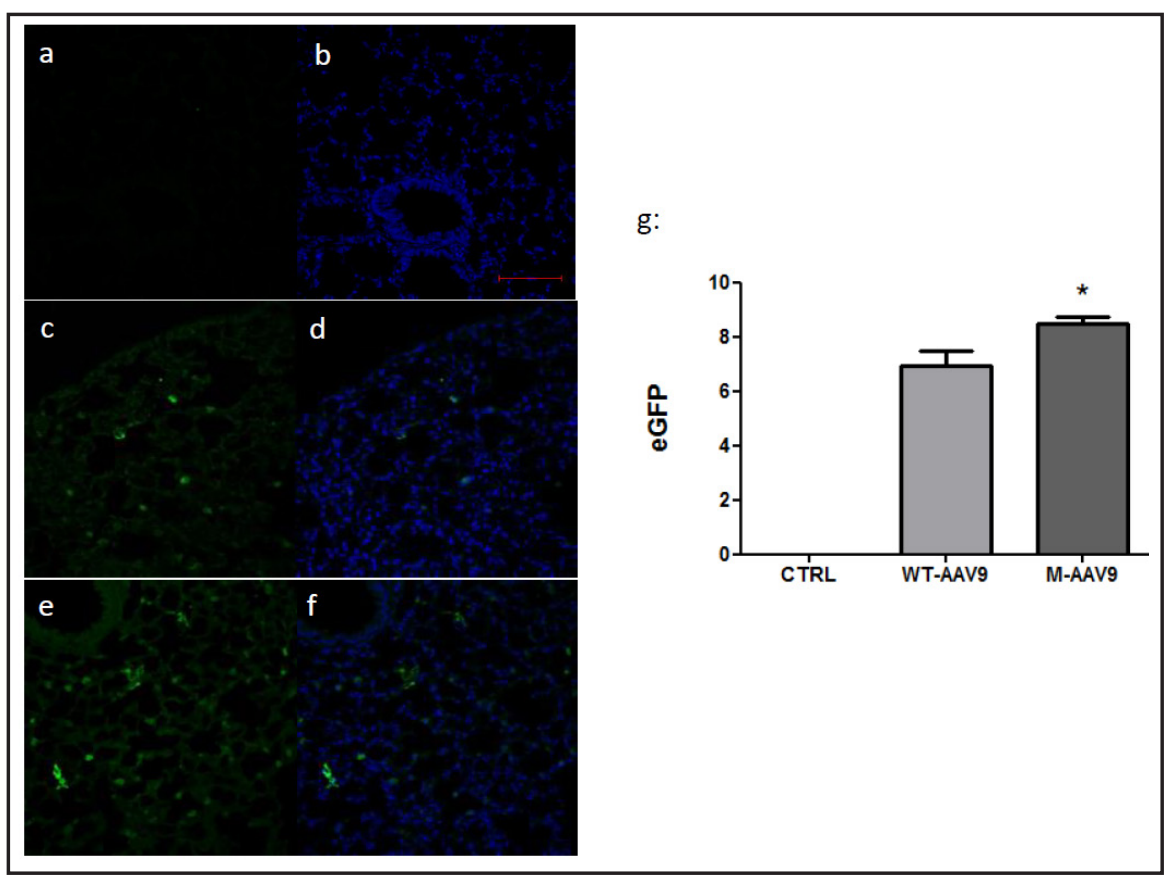
staining eGFP and nucleus of tissue cells stained with TO-PRO-3 (B, D, and F). All pictures of eGFP immunostaining were taken using the same exposure time in order to compare eGFP intensity. Calibration bar represents $100 \mu \mathrm{M}$. (F) Real-time PCR analysis of eGFP transcription. Animals received intratracheal instillation of saline (CTRL, $50 \mu \mathrm{l}$ of saline), wild-type AAV9 (WT-AAV9, $10^{10} \mathrm{vg} / 50 \mu \mathrm{l}$ of saline), or tyrosine-mutant AAV9 (M-AAV9, $10^{10} \mathrm{vg} / 50 \mu \mathrm{l}$ of saline). The $y$ axis represents the relative level of eGFP gene calculated as the ratio of the housekeeping gene acidic ribosomal phosphoprotein P0 expression (36B4). Values are means \pm SEM of 6 animals/group. *Significantly different from the WT-AAV9 group $(P<0.05)$.

\section{KARGER}




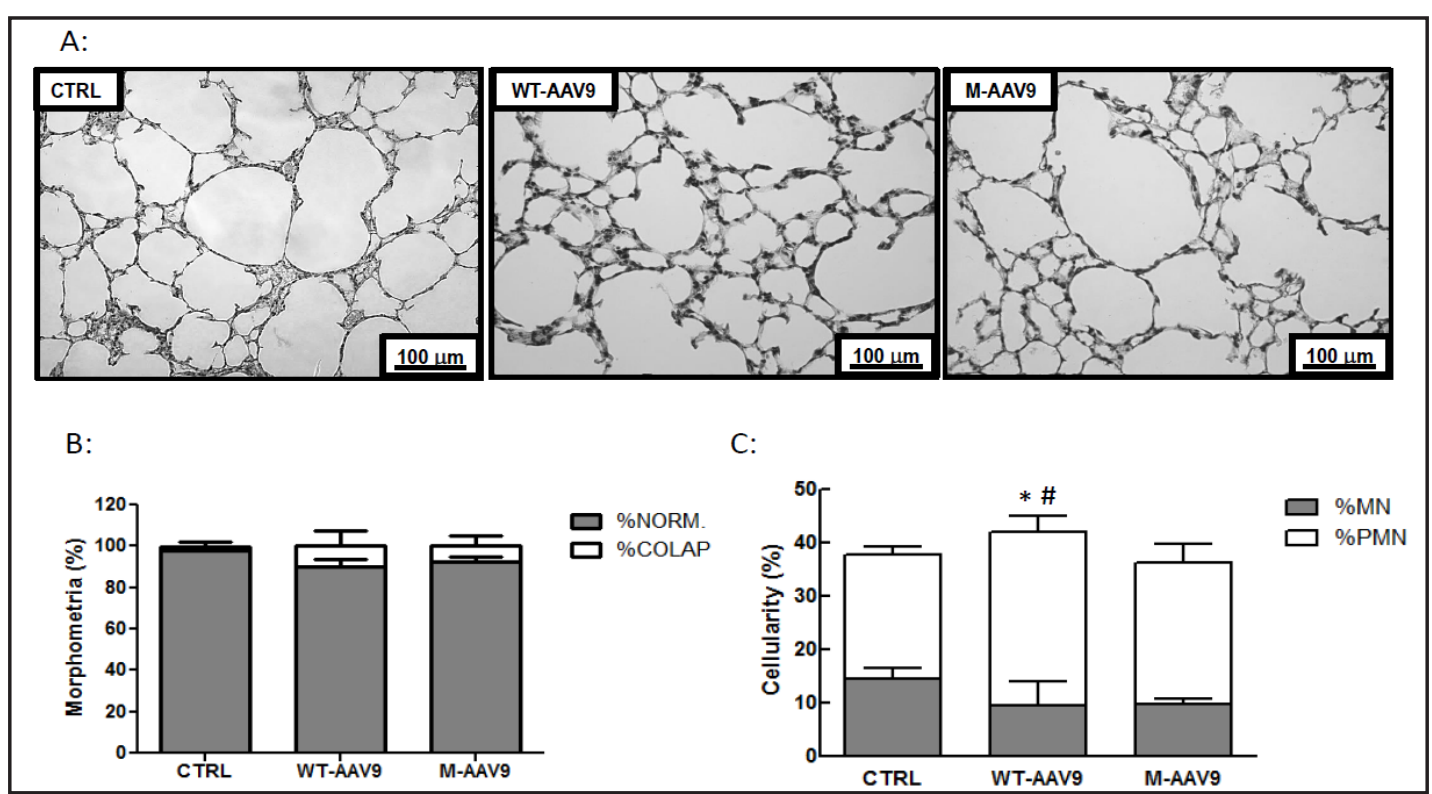

Fig. 3. (A) Representative photomicrographs of lung stained with hematoxylin-eosin on day 28. (B) Lung morphometry. (C) Lung tissue cellularity. Animals received intratracheal instillation of saline (CTRL, 50 $\mu \mathrm{l}$ of saline), wild-type AAV9 (WT-AAV9, $10^{10} \mathrm{vg} / 50 \mu \mathrm{l}$ of saline), or tyrosine-mutant AAV9 (M-AAV9, $10^{10}$ $\mathrm{vg} / 50 \mu \mathrm{l}$ of saline).Values are means \pm SEM of 6 animals/group. *Significantly different from the CTRL group. \#Significantly different from the WT-AAV9 group.

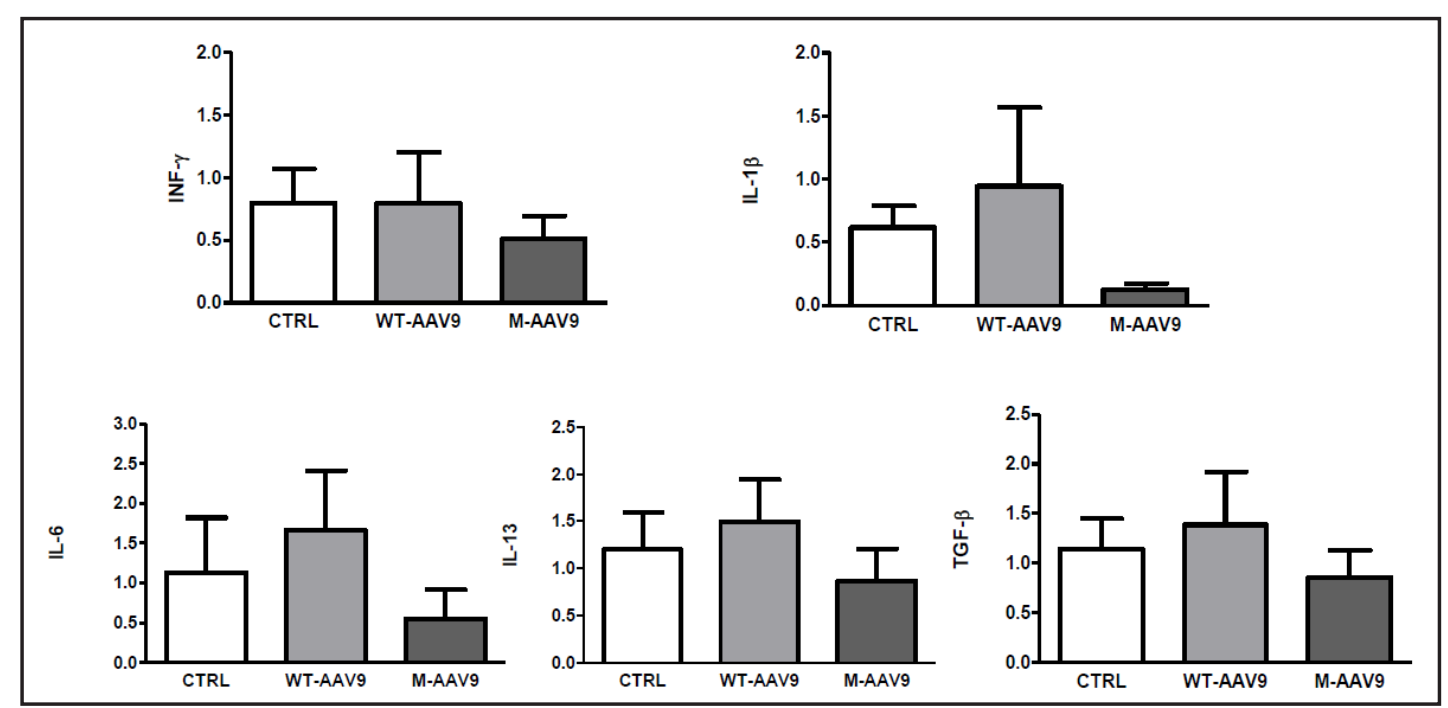

Fig. 4. Real-time PCR analysis of cytokine and growth factor mRNA expression. (A) IL-1 $\beta$, IL-6, IL-13, IFN- $\gamma$, and TGF- $\beta$. Data are normalized to housekeeping gene acidic ribosomal phosphoprotein P0 expression (36B4). Animals received intratracheal instillation of saline (CTRL, $50 \mu \mathrm{l}$ of saline), wild-type AAV9 (WTAAV9, $10^{10} \mathrm{vg} / 50 \mu \mathrm{l}$ of saline), or tyrosine-mutant AAV9 (M-AAV9, $10^{10} \mathrm{vg} / 50 \mu \mathrm{l}$ of saline).The $y$ axis represents the fold increase compared with CTRL. Values are means \pm SEM of 6 animals per group.

(Fig. 3). The fractional area of collapsed alveoli did not differ between the groups (Fig. 3B). However, the number of polymorphonuclear cells was higher in the WT-AAV9 group (32.52 $\pm 0.08, n=5, P<0.05)$ than in CTRL group $(23.24 \pm 0.08, n=5, P<0.05)$ and the M-AAV9 group $(26.49 \pm 0.08, n=5, P<0.05)$ (Fig. $3 \mathrm{C}$ ). These results suggest that the administration of capsid-mutant AAV9 vectors in mice lungs was safe and better tolerated compared with their wild-type counterparts. 
Cytokine and growth factor mRNA levels in lung tissue

Immune response mediators were analyzed to define whether one dose of AAV9 vectors to the airways induced inflammatory processes. Our findings demonstrate that the instillation of AAV9 vectors did not result in changes in proinflammatory cytokines (IL$1 \beta$ and IL-6), IL-13 (a Th2 response marker), IFN- $\gamma$ (a Th1 response marker), and TGF- $\beta$ (a profibrotic agent) mRNA levels in any group (Fig. 4).

\section{Lung mechanics}

Lung function was observed to evalu-

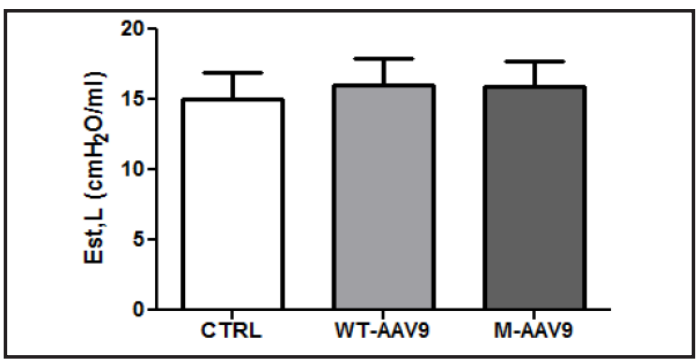

Fig. 5. Static lung elastance. Animals received intratracheal instillation of saline (CTRL, $50 \mu \mathrm{l}$ of saline), wild-type AAV9 (WT-AAV9, $10^{10} \mathrm{vg} / 50 \mu \mathrm{l}$ of saline), or tyrosine-mutant AAV9 (M-AAV9, $10^{10}$ $\mathrm{vg} / 50 \mu \mathrm{l}$ of saline). Values are means \pm SEM of 6 animals per group (10 determinations per animal).

ate whether the administration of AAV9 vectors caused lung damage. Our results show that static lung elastance was similar in the three groups (Fig. 5).

\section{Discussion}

Despite significant advancements with AAV vectors for gene therapy in animals and humans, it is well recognized that host and vector-related immune challenges need to be overcome for long-term gene transfer. In addition, there is enough evidence that AAV particles are subjected to cellular phosphorylation/uniquitination leading to proteasome-mediated degradation and loss of the viral particles [27]. To circumvent this degradation, rational bioengineering of AAV capsid is a prime tool by which specific amino acid residues can be suitably replaced by compatible residues (tyrosine residues were exchanged for phenylalanine) to create vectors with lower host immune response and a higher rate intracellular trafficking rate $[16,28]$.

Studies performed in 2010 reported that site-directed mutagenesis of surface-exposed tyrosine residues on viral capsids leads to improvement in intracellular trafficking of the mutant vectors and in the transduction efficiency of single tyrosine-mutant vectors in human cells. Tyrosine-mutant AAV vectors were used in different target sites such as the retina [17], skeletal muscle [29], human hematopoietic stem cells [30], fibroblasts and mesenchymal stem cells [31], kidney [6] where they showed efficient transduction compared with the wild-type vectors [28]. Although its ability to transduce various tissues is well known, the present work is the first study to examine the transduction characteristics of the AAV9 capsid mutant in lungs and its impact on respiratory function.

Among many viral gene transfer vectors currently available, self-complementary tyrosine-mutant AAV9 is a good candidate for the genetic treatment of airway diseases. Moreover, AAV9 vectors have been used for transgene expression in different organs $[6,17,27]$ transduce murine alveolar and nasal epithelia and can be readministered [9].

We examined whether single tyrosine mutations could improve the transduction efficiency of AAV9 vectors in mouse lung. The transgene expression efficacy of the Y731F AAV9 vector was $30 \%$ higher than the wild-type AAV9 vector (Fig. 2G). The increased eGFP expression of M-AAV9 group compared to WT-AAV9 in the lungs, analyzed by real-time PCR, was confirmed by immunohistochemistry (Fig. 2). Our results are consistent with previous reports that systemic Y731F AAV9 injection resulted in efficient skeletal muscle transduction in neonatal dogs [29]. In addition, Petrs-Silva et al. [17] reported that tyrosine-mutant AAV9 (Y731F) enhanced the efficiency of transduction in the retinal ganglion cell layer after intravitreal injection, suggesting that mutations in surface-exposed capsid tyrosine residues in AAV is predicted to allow the vectors to escape the proteasome degradation pathway and thus promote more vector genome delivery to the nucleus and more aggressive transgene expression.

\section{KARGER}




\section{Cellular Physiology Cell Physiol Biochem 2016;39:544-553

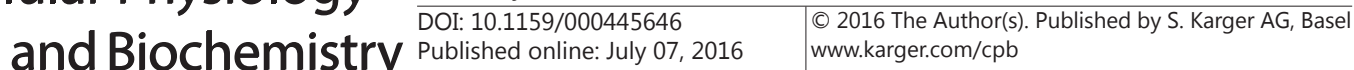 \\ Martini et al.: Mutation in AAV9 Improves Gene Transfer to the Lung}

This optimized capsid-mutant AAV9 have the potential to become important tools for gene transfer as well for therapeutic application in cystic fibrosis (CF), disease caused by mutations in cystic fibrosis transmembrane conductance regulator (CFTR) gene which encodes an epithelial chloride and bicarbonate ion channel [32]. Most of CF patients develop progressive lung injury with airway mucus obstruction, bacterial infection, and inflammation despite intense symptomatic treatments, which do not treat the molecular cause of the disease (defective CFTR protein) [33, 34].

In vitro studies conducted by Ramalho el al. [35] on human nasal epithelial cells of CF patients have shown that achieving as little as $5 \%$ of the normal level of wildtype CFTR activity is sufficient to eliminate the severe pulmonary complication of the disease. Other in vivo studies have suggested that achieving 10 to $35 \%$ of the normal level of wildtype CFTR activity is necessary [36]. Therefore, the major disease manifestations could be eliminated with small amounts of functional CFTR delivered by an efficient gene therapy that can transfer the normal CFTR gene to the respiratory cells.

AAV vectors have gained wide acceptance as in vivo gene transfer vectors due to their very mild proinflammatory profile [37]. However, it has been reported that in murine and human plasmacytoid dendritic cells in vitro, the AAV vector interacts with the innate immune system through the Toll-like receptor (TLR)9/MyD88 and type I interferon cascade $[38,39]$. AAV vectors also trigger nuclear factor $\mathrm{kB}-$ dependent production of cytokine and chemokine release in mouse liver, and MyD88 signaling in B cells also seems to control the production of capsid-specific T helper 1 antibody responses [40, 41].

Our findings show that intratracheal instillation of AAV9 vectors did not elicit an increase in the mRNA levels of inflammatory cytokines (IL-1 $\beta$, IL-6, IL-13, and IFN- $\gamma$ ) or TGF- $\beta$, a critical chemical mediator of lung remodeling, in the lungs of the experimental animals.

It is well known that immunological reactions can cause changes in lung function [42]. In the present study, pulmonary mechanics were examined and static lung elastance was similar in all experimental groups (Fig. 5). Moreover, the results of the pulmonary histology corroborate with the pulmonary mechanics, showing no alterations in lung parenchyma (Fig. 3B). However, pulmonary histology showed lung tissue neutrophilic infiltration in WT-AAV9 group (Fig. 3C); this histological change was not sufficient to change the lung mechanics.

In summary, the present study analyzed the transduction capacity of AAV9 vectors and the impact on lung function. The M-AAV9 vectors enhanced eGFP transgene levels in mouse lung, observed both by real-time RT-PCR and immunofluorescence, showing that this vector is more efficient at gene transfer than WT-AAV9. Furthermore, the administration of MAAV8 did not cause inflammation or morphometric changes in the lungs, thus keeping lung mechanics unchanged. Hence, tyrosine-mutant AAV9 is safe and can successfully transduce pulmonary cells, indicating that AAV9 should be the vector of choice for studies involving gene transfer to the lung.

Our data are new and of great impact for the development of translational research; gene therapy has potential to improve the prognosis and reduce mortality for pulmonary diseases.

\section{Acknowledgments}

The authors would like to express their gratitude to Mr Andre Benedito da Silva for technical support. This study was supported by the Brazilian Council for Scientific and Technological Development (CNPq), Rio de Janeiro State Research Supporting Foundation (FAPERJ), and Coordination for the Improvement of Higher Level Personnel (CAPES).

\section{Disclosure Statement}

The authors have no competing interests to declare. 


\section{Cellular Physiology Cell Physiol Biochem 2016;39:544-553

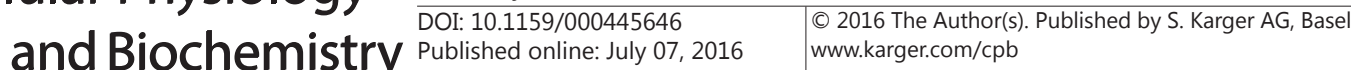

Martini et al.: Mutation in AAV9 Improves Gene Transfer to the Lung

\section{References}

1 Moss RB, Milla C, Colombo J, Accurso F, Zeitlin PL, Clancy JP, Spencer LT, Pilewski J, Waltz DA, Dorkin HL, Ferkol T, Pian M, Ramsey B, Carter BJ, Martin DB, Heald AE: Repeated aerosolized AAV-CFTR for treatment of cystic fibrosis: a randomized placebo-controlled phase 2B trial. Hum Gene Ther 2007;18:726-732.

2 Halbert CL, Madtes DK, Vaughan AE, Wang Z, Storb R, Tapscott SJ, Miller AD: Expression of human alpha1-antitrypsin in mice and dogs following AAV6 vector-mediated gene transfer to the lungs. Mol Ther 2010;18:1165-1172.

3 Devaney J, Curley GF, Hayes M, Masterson C, Ansari B, O’Brien T, O’Toole D, Laffey JG: Inhibition of pulmonary nuclear factor kappa-B decreases the severity of acute Escherichia coli pneumonia but worsens prolonged pneumonia. Crit Care 2013;17:R82.

4 Gubrij IB, Martin SR, Pangle AK, Kurten R, Johnson LG: Attenuation of monocrotaline-induced pulmonary hypertension by luminal adeno-associated virus serotype 9 gene transfer of prostacyclin synthase. Hum Gene Ther 2014;25:498-505.

$5 \quad$ He SS, Shi HS, Yin T, Li YX, Luo ST, Wu QJ, Lu L, Wei YQ, Yang L: AAV-mediated gene transfer of human pigment epithelium-derived factor inhibits Lewis lung carcinoma growth in mice. Oncol Rep 2012;27:11421148.

6 Qi YF, Li QH, Shenoy V, Zingler M, Jun JY, Verma A, Katovich MJ, Raizada MK: Comparison of the transduction efficiency of tyrosine-mutant adeno-associated virus serotype vectors in kidney. Clin Exp Pharmacol Physiol 2013;40:53-55.

7 Schultz BR, Chamberlain JS: Recombinant adeno-associated virus transduction and integration. Mol Ther 2008;16:1189-1199.

8 Grimm D, Kay M: From virus evolution to vector revolution: use of naturally occurring serotypes of adenoassociated virus (AAV) as novel vectors for human gene therapy. Curr Gene Ther 2003;3:281-304.

9 Limberis MP, Vandenberghe LH, Zhang L, Pickles RJ, Wilson JM: Transduction efficiencies of novel AAV vectors in mouse airway epithelium in vivo and human ciliated airway epithelium in vitro. Mol Ther 2009;17:294-301.

10 Flotte TR, Zeitlin PL, Reynolds TC, Heald AE, Pedersen P, Beck S, Conrad CK, Brass-Ernst L, Humphries M, Sullivan K, Wetzel R, Taylor G, Carter BJ, Guggino WB: Phase I trial of intranasal and endobronchial administration of a recombinant adeno-associated virus serotype 2 (rAAV2)-CFTR vector in adult cystic fibrosis patients: a two-part clinical study. Hum Gene Ther 2003;14:1079-1088.

11 Halbert CL, Miller AD, Namara SMC, Emerson J, Gibson RL, Ramsey B, Aitken ML: Prevalence of neutralizing antibodies against cystic fibrosis and normal populations: implications for gene therapy using AAV vectors. Hum Gene Ther 2006;17:440-447.

12 Lassance RM, Caroline PP, Martini SV, Castiglione RC, Gutierrez TM, Abreu SC, Antunes MA, Xisto DG, Cebotaru L, Petrs-Silva H, Zin WA, Guggino WB, Linden R, Rocco PR, Morales MM: Does the use of recombinant AAV2 in pulmonary gene therapy damage lung function? Respir Physiol Neurobiol 2008;160:91-98.

13 Sen D, Gadkari RA, Sudha G, Gabriel N, Kumar YS, Selot R, Samuel R, Rajalingam S, Ramya V, Nair SC, Srinivasan N, Srivastava A, Jayandharan GR: Targeted modifications in adeno-associated virus serotype 8 capsid improves its hepatic gene transfer efficiency in vivo. Hum Gene Ther Methods 2013;24:104-116.

14 Kotterman MA, Schaffer DV: Engineering adeno-associated viruses for clinical gene therapy. Nat Rev Genet 2015;15:445-451.

15 Qiao C, Yuan Z, Li J, Tang R, Li J, Xiao X: Single tyrosine mutation in AAV8 and AAV9 capsids is insufficient to enhance gene delivery to skeletal muscle and heart. Hum Gene Ther Methods 2012;23:29-37.

16 Zhong L, Li B, Mah CS, Govindasamy L, Agbandje-McKenna M, Cooper M, Herzog RW, Zolotukhin I, Warrington KH Jr, Weigel-Van Aken KA, Hobbs JA, Zolotukhin S, Muzyczka N, Srivastava A: Next generation of adeno-associated virus 2 vectors: point mutations in tyrosines lead to high-efficiency transduction at lower doses. Proc Natl Acad Sci U S A 2008;105:7827-7832.

17 Petrs-Silva H, Dinculescu A, Li Q Min S-H, Chiodo V, Pang J-J, Zhong L, Zolotukhin S, Srivastava A, Lewin AS, Hauswirth WW: High-efficiency transduction of the mouse retina by tyrosine-mutant AAV serotype vectors. Mol Ther 2009;17:1463-1471.

18 Martino AT, Basner-Tschakarjan E, Markusic DM, Finn JD, Hinderer C, Zhou S, Ostrov DA, Srivastava A, Ertl HC, Terhorst C, High KA, Mingozzi F, Herzog RW: Engineered AAV vector minimizes in vivo targeting of transduced hepatocytes by capsid-specific CD8+ T cells. Blood 2013;121:2224-2233.

19 Gao G, Vandenberghe LH, Alvira MR, Lu Y, Calcedo R, Zhou X, Wilson JM: Clades of adeno-associated viruses are widely disseminated in human tissues. J Virol 2004;78:6381-6388.

20 Bish LT, Morine K, Sleeper MM, Sanmiguel J, Wu D, Gao G, Wilson JM, Sweeney HL: Adeno-associated virus (AAV) serotype 9 provides global cardiac gene transfer superior to AAV1, AAV6, AAV7, and AAV8 in the mouse and rat. Hum Gene Ther 2008;19:1359-1368. 


\section{Cellular Physiology Cell Physiol Biochem 2016;39:544-553 \begin{tabular}{ll|l} 
and Biochemistry Published online: July 07, 2016 & $\begin{array}{l}\text { (c) 2016 The Author(s). Published by S. Karger AG, Basel } \\
\text { www.karger.com/cpb }\end{array}$
\end{tabular}}

21 Foust KD, Nurre E, Montgomery CL, Hernandez A, Curtis M, Kaspar BK: Intravascular AAV9 preferentially targets neonatal neurons and adult astrocytes. Nat Biotechnol 2009;27:59-65.

22 Wang RL, McLaughlin T, Cossette T, Tang Q, Foust K, Campbell-Thompson M, Martino A, Cruz P, Loiler S, Mueller C, Flotte TR: Recombinant AAV serotype and capsid mutant comparison for pulmonary gene transfer of alpha-1-antitrypsin using invasive and noninvasive delivery. Mol Ther 2009;17:81-87.

23 Akache B, Grimm D, Pandey K, Yant SR, Xu H, Kay MA: The 37/67-kilodalton laminin receptor is a receptor for adeno-associated virus serotypes 8, 2, 3, and 9. J Virol 2006;80:9831-9836.

24 Martin EL, Sheikh TA, Leco KJ, Lewis JF, Veldhuizen RA: Contribution of alveolar macrophages to the response of the TIMP-3 null lung during a septic insult. Am J Physiol Lung Cell Mol Physiol 2007;293:L779789.

25 Gill J, ed: Models of Lung Disease - Microscopy and Structural Methods. New York: Marcel Dekker; 1990, pp 199-247.

26 Martini SV, da Silva AL, Ferreira D, Gomes K, Ornellas FM, Lopes-Pacheco M, Zin E, Petrs-Silva H, Rocco PR, Morales MM: Single tyrosine mutation in AAV8 vector capsid enhances gene lung delivery and does not alter lung morphofunction in mice. Cell Physiol Biochem 2014;34:681-690.

27 Petrs-Silva H, Dinculescu A, Li Q Deng W-T, Pang J-J, Min S-H, Chiodo V, Neeley AW, Govindasamy L, Bennett A, Agbandje-McKenna M, Zhong L, Li B, Jayandharan GR, Srivastava A, Lewin AS, Hauswirth WW: Novel properties of tyrosine-mutant AAV2 vectors in the mouse retina. Mol Ther 2011;19:293-301.

28 Sen D: Improving clinical efficacy of adeno associated vectors by rational capsid bioengineering. J Biomed Sci 2014;21:103.

29 Hakim CH, Yue Y, Shin J-H, Williams RR, Zhang K, Smith BF, Duan D: Systemic gene transfer reveals distinctive muscle transduction profile of tyrosine mutant AAV-1, -6 , and -9 in neonatal dogs. Mol Ther Methods Clin Dev 2014;1:14002.

30 Song L, Li X, Jayandharan GR, Wang Y, Aslanidi GV, Ling C, Zhong L, Gao G, Yoder MC, Ling C, Tan M, Srivastava A: High-efficiency transduction of primary human hematopoietic stem cells and erythroid lineage restricted expression by optimized AAV6 serotype vectors in vitro and in a murine xenograft model in vivo. PLoS One 2013;8:e58757.

31 Li M, Jayandharan GR, Li B, Ling C, Ma W, Srivastava A, Zhong L: High-efficiency transduction of fibroblasts and mesenchymal stem cells by tyrosine-mutant AAV2 vectors for their potential use in cellular therapy. Hum Gene Ther 2010;21:1527-1543.

32 Morales MM, Capella MA, Lopes AG: Structure and function of the cystic fibrosis transmembrane conductance regulator. Braz J Med Biol Res 1999;32:1021-1028.

33 Elborn JS: Cystic fibrosis. Lancet DOI: 10.1016/S0140-6736(16)00576-6.

34 De Boeck K, Amaral MD: Progress in therapies for cystic fibrosis. Lancet Respir Med DOI: 10.1016/S22132600(16)00023-0.

35 Ramalho AS, Beck S, Meyer M, Penque D, Cutting GR, Amaral MD: Five percent of normal cystic fibrosis transmembrane conductance regulator RNA ameliorates the severity of pulmonary disease in cystic fibrosis. Am J Respir Cell Mol Biol 2002; 27:619-627.

36 Kerem E, Corey M, Kerem BS, Rommens J, Markiewicz D, Levison H, Tsui LC, Durie P: The relation between genotype and phenotype in cystic fibrosis - analysis of the most common mutation (delta F508). N Engl J Med 1990;323:1517-1522.

37 Vandendriessche T, Thorrez L, Acosta-Sanchez A, Petrus I, Wang L, Ma L, Iwasaki Y, Gillijns V, Wilson JM, Collen D, Chuah MK: Efficacy and safety of adeno-associated viral vectors based on serotype 8 and 9 vs. lentiviral vectors for hemophilia B gene therapy. J Thromb Haemost 2007;5:16-24.

38 Suzuki M, Bertin TK, Rogers GL, Cela RG, Zolotukhin I, Palmer DJ, Ng P, Herzog RW, Lee B: Differential type I interferon-dependent transgene silencing of helper-dependent adenoviral vs. adeno-associated viral vectors in vivo. Mol Ther 2013;21:796-805.

39 Zhu J, Huang X, Yang Y: The TLR9-MyD88 pathway is critical for adaptive immune responses to adeno- associated virus gene therapy vectors in mice. J Clin Invest 2009;119:2388-2398.

40 Sudres M, Ciré S, Vasseur V, Brault L, Da Rocha S, Boisgérault F, Le Bec C, Gross DA, Blouin V, Ryffel B, Galy A: MyD88 signaling in B cells regulates the production of Th1-dependent antibodies to AAV. Mol Ther 2012;20:1571-1581.

41 Jayandharan GR, Aslanidi G, Martino AT, Jahn SC, Perrin GQ Herzog RW, Srivastava A: Activation of the NF-kappaB pathway by adeno-associated virus (AAV) vectors and its implications in immune response and gene therapy. Proc Natl Acad Sci USA 2011;108:3743-3748.

42 Da Silva AL, Martini SV, Abreu SC, Samary CDS, Diaz BL, Fernezlian S, de Sá VK, Capelozzi VL, Boylan NJ, Goya RG, Suk JS, Rocco PR, Hanes J, Morales MM: DNA nanoparticle-mediated thymulin gene therapy prevents airway remodeling in experimental allergic asthma. J Control Release 2014;180:125-133. 